\title{
KREATIVA PRIMARY SCHOOL MANAGEMENT (QuALITATIVE DESCRIPTIVE ANALYSIS STUDIES)
}

\author{
Sutji Harijanto $^{\left.a^{*}\right)}$, Griet Helena Laihad ${ }^{b)}$, Chafid Sugianto ${ }^{b)}$ \\ a) Sari Gaperi Housing Complex, Bekasi, Indonesia \\ ${ }^{b)}$ Universitas Pakuan, Bogor, Indonesia \\ ${ }^{*}$ Corresponding Author: sutjihar@unpak.ac.id
}

Article history: received 09 January 2021; revised 13 February 2021; accepted 26 February 2021

\begin{abstract}
One of the primary schools located in Bogor City, West Java which has the concept of improving the students competence accompanied by Islamic religious education, character, environment and provide learning opportunities for children with special needs to learn together with regular students is Kreativa Primary School. This journal is factually written based on the data obtained from the source. from the research results directly to the object location. This study aims to obtain a fact-based picture in the form of data and information on the management of the 5 pillars of the Kreativa Elementary School: Islamic, Green, Leadership, Children Friendly, and Inclusive in order to develop Islamic morals for students. This research uses qualitative methods, with the researcher as an instrument. The data collection techniques used were interviews, observation, and documentation study. Based on existing data and information, it can be concluded that the management function of planning, organizing, directing, and controlling plays an important role in achieving school goals. School management strives to achieve the goal of developing Islamic morals for students through the application of 5 pillars: Islamic, Green, Leadership, Children Friendly, and Inclusive as the basis for educational programs at Kreativa Elementary School. To achieve these goals requires planning that has a strong concept to achieve goals, organizing that is tailored to the needs of the school, directing resources according to the program that has been planned and organized, and control that includes all components of the educational program.
\end{abstract}

Keywords: primary school management; 5 pillars; Islamic morals

\section{INTRODUCTION}

Kreativa Elementary School provides a school concept that teaches Islamic religious values, cares for the environment, forms leadership and child-friendly behavior by providing comfort for students while studying, besides that the teacher also facilitates the interests of all types of students, including children with special needs can receive education together with regular students as an inclusive program. They applies the basic 5 pillars: Islamic, Green, Leadership, Children Friendly, and Inclusive to accommodate the achievement of school goals. The application of the 5 pillars as a school philosophy seeks to solve today's problems, but also has a positive impact on student and school achievement. The achievements that have been obtained by students and the school, also the uniqueness in the application of basic schools make it an attraction to explore the management of the Kreativa Elementary School is based on 5 pillars: Islamic, Green, Leadership, Children Friendly, and Inclusive in order to develop Islamic morals for students.

Management is the science of planning, organizing, directing, motivating, and controlling human resources and working mechanisms to achieve goals (Siswanto [1]). The process in the management of an organization consists of planning which is planned in the early stages then the assignment is arranged and directed in its implementation. Motivation is also carried out to make resources more motivated to achieve organizational goals through the implemented program. The final stage is control to provide feedback on the processes that have been implemented in the organization so as not to deviate from organizational goals. Management is also an art of organizational management. This management process takes place continuously in which not only contains capabilities but is also supported by the use of human resource skills in the form of energy and thoughts which are specifically utilized to be able to do work effectively and efficiently through careful planning, organization, and supervision so that it is obtained. optimal results (Tatang [2]). This is also in line with R. Terry's statement (in Arif and Zulkarnain [3]) which states that management is a process consisting of planning, organizing, mobilizing and controlling actions to determine and achieve predetermined goals through the use of human resources. and other resources. Based on the description, synthesis can be drawn that management is a science to organize an organization by utilizing all existing organizational resources effectively and efficiently to achieve the goals to be achieved. Organizations must be managed by managers who have competent abilities so that they can achieve the goals expected by the organization through effective and efficient use of resources.

The management discussed in this study is related to school management based on 5 pillars: Islamic, Green. Leadership, Children Friendly, and Inclusive in order to develop Islamic morals for students. Islamic can be 
interpreted as a conscious human effort to reflect the relatively limited interpretations of Islamic principles and ideals (Hasan [4]). Muslim humans apply Islamic religious principles in their daily lives. Islamic, namely the effort to believe that God exists and provide His revelation to guide His people which is applied through the behavior of daily life in accordance with the principles of Islamic teachings. Cabral [5] states "Green attitude has been referred as the feelings which includes evaluative action to engage in environmental performance". This greening behavior is referred to as actions to protect the environment, so that humans can keep nature properly. Green can be defined as an attitude based on awareness and concern for respecting the natural environment. Leadership principles focus on helping students to take responsibility for their lives, work with others effectively, and do the right thing even when no one is paying attention (Covey [6]). Leadership can be defined as the value or attitude of a person to influence oneself and others to achieve the goals set and to be responsible for the decisions they make. The application of the concept of childfriendly education has the aim of forming children with positive characters (akhlaqul karimah) with a compassionate and humanistic-based approach (Risminawati [7]). When education applies the child-friendly concept, there will be a positive character formation of students. Children friendly, especially in schools, is an action to provide comfort to children in learning and provide opportunities to develop student interests. Inclusive education is closely related to children with special needs, but Robinson[8]) states that the process in the education system provides equal opportunities and participation and respects differences and social justice in learning, whether it's normal individuals or those with special needs. Inclusive education can be synthesized, namely a system that places normal children and children with special needs in one class to provide equal opportunities in learning. Mahmud [9] explains more simply, Islamic morals, which are morals based on Islamic teachings or Islamic morals. Islamic morals are traits that are embedded in the soul and influence human behavior based on Islamic teachings.

\section{RESEARCH METHODS}

The research method used is descriptive qualitative method which aims to describe and conduct critical analysis objectively based on real data and information that exist and occur in the field regarding school management based on 5 pillars: Islamic, Green. Leadership, Children Friendly, and Inclusive in order to develop Islamic morals for students. The research was conducted at Kreativa Elementary School, Bogor, which applies 5 pillars: Islamic, Green. Leadership, Children Friendly, and Inclusive as the basis for its education programs.

This study relies on researchers as the main instrument. Collecting data and information uses in-depth studies through the process of interviews, observations, and documentation studies regarding symptoms, problems, and facts or realities that exist in the object of research.
Furthermore, the process of exploratory understanding is carried out by collecting as much information as possible from the informants supported by observation data and documentation to then be analyzed and described, in order to obtain an in-depth interpretation.

\section{RESULTS AND DISCUSSION}

The findings of the research results based on an intersite analysis of the four research sub-focuses obtained through interviews, observation, and documentation study of eight informants at the Kreativa Elementary School are described as follows:

\section{Sub Focus 1: Planning}

Based on the results of the control and the objectives to be achieved, Kreativa Elementary School prepares an educational program plan that is set since the beginning of the year with regard to the results of the previous year's evaluation and through the results of discussions and input from the Foundation and the School Committee. This is in line with the opinion of Afifudin (in Sutikno [9]) explaining that planning is the whole process of thinking carefully about what will be done to achieve predetermined goals.

Planning for the admission of ordinary children and children with special needs as input to the Kreativa Elementary School for the first priority relies on graduates from Kreativa Kindergarten, and the second comes from outside, namely the nearby kindergarten which is still within a radius of one Tanah Sareal Village, Bogor City. School learning planning is arranged according to themes and concepts. Education is based on the 5 pillars of the school, as follows:

a. Schools teach Islamic religious values according to Islamic pillar.

b. The school fosters concern for the environment according to Green pillar.

c. Schools instill the spirit of leadership of students according to Leadership pillar.

d. Child-friendly schools, explore the potential of students, and provide learning materials as the child's age development needed according to Children Friendly pillars..

e. Schools provide opportunities for children with special needs to learn together with ordinary children in one class, instill the value of mutual respect for children's rights to education, respect for their friends, and care for fellow humans even though they are different, according to the Inclusive pillar.

The goals and objectives of education implemented at the Kreativa Elementary School are contained in the school's vision, namely to create an outstanding school based on a child-friendly environment and prioritize the achievement of Islamic morals and the leadership values of each student. The basic 5 pillars: Islamic, Green, Leadership, Children Friendly, and Inclusive serve as a guide to explore the potential and develop Islamic morals of students. In the 
vision of school, it has clearly included elements of the pillars of Islamic, Green, Leadership, and Children Friendly, but for the Inclusive pillar it has not been explicitly implied that in concrete terms the school has committed to running an inclusive education program.

Planning for educational programs in schools has been based on 5 pillars which are integrated with the 2013 curriculum. The preparation of educational programs has also paid attention to the evaluations carried out by schools. The curriculum for students with special needs uses the 2013 curriculum which is modified according to the needs of students. The school has compiled an educational concept which is subsequently outlined in the annual education program, semester education program/syllabus, and weekly education program / RPP. The annual education program is prepared by school management, then legalized at the foundation's work meeting, then socialized and assignments divided in school work meetings. Furthermore, the facilitator coordinates with the principal and deputy principal to prepare a semester education program/ syllabus and a weekly education program.

\section{Sub Focus 2: Organizing}

At the organizing stage, the division of tasks has been carried out through the distribution of the school organizational structure according to the needs. Human resources of Kreativa Elementary School carry out the management and utilization of other resources for the implementation of learning activities. This is in line with the opinion of Nurochim [10] which states that organizing is the process of preparing an organizational structure that is adjusted to the goals, sources and environment to choose the right people and place support for facilities and infrastructure to achieve predetermined goals.

Kreativa Elementary School is a school founded by the Indonesian Muslimah Apirasi Foundation (Yasmina) so that part of the school management is assisted by the foundation management. The organizational structure of the Kreativa School consists of foundation management which delegates authority to the management of Kreativa Elementary School. Yasmina Foundation management is led by the Director of the Foundation consisting of Human Resources and General Management, Quality Assurance Management, Public Relations Management, School Financial Management, Cooperative Management and 3 School Management Units consisting of Kreativa Kindergarden, Elementary School, and Junior High School education units. The management of Kreativa Elementary School is led by the Principal of the Elementary School, assisted by 4 Deputy Principals, namely the Deputy Principal of High Level Schools, Deputy Head of Low Level Schools, Deputy Head of School for Al-Quran, and the Coordinator of PPABK (Learning Program for Children with Special Needs) The organizational structure is arranged based on the division of tasks and functions costumized to the needs of the school. Kreativa Elementary School's organizational structure tends to remain constant, but the filling of positions is flexible or there may be rotation of positions. The occupants in school management are discussed by the Foundation Management and the Principal. Subsequently, the assignment of positions is legalized through a Decree issued by the foundation's directorate.

Educational management resources at Kreativa Elementary School include human resources, facilities and infrastructure resources, technology resources, and financial resources. Human resources are the main resources in charge of managing other resources for the benefit of managing education in schools. The quality of human resources in school management is given great attention, from recruitment to evaluation. The foundation has always improved the competence of human resources in order to keep pace with the times. Facilities and infrastructure resources also receive the foundation's attention as resources to support the education management process in schools. Educational infrastructure is provided and well managed in order to make students comfortable to learn. The existing learning technology resources are sufficient to provide convenience both academically and administratively. The use of Technology, Information and Communication (ICT) has been used to facilitate the management of existing resources in schools effectively and efficiently. Financial resources as administrative support are also capable of supporting other resources. The financial support for Kreativa Elementary School comes from the School Operational Assistance from the government, to be precise, the Bogor City Education Office and contributions or donations that come from the parents of students.

The criteria for prospective students to register at Kreativa Elementary School are in accordance with the provisions of the Ministry of Education and Culture. Prospective students are at least 6 years old. Kreativa Elementary School opens opportunities for ordinary children and children with special needs to study together at school through an inclusive education program. Prospective students of Kreativa Elementary School always go through an interview process and are observed by psychologists and facilitators. Observations were made to see the maturity of students such as understanding speech and adaptation abilities in school, while interviews were conducted with parents and prospective students and given an explanation of the educational program at Kreativa Elementary School. Prospective students with special needs always go through the initial screening stages and psychological tests. The initial screening was carried out by the PPABK Coordinator through interviews and preliminary observations to see the special needs of students. Furthermore, prospective students are subjected to a psychologist test to see in detail the categories of the prospective students' special needs, including those in the mild, moderate, or severe categories. The psychologist provides a record of the test results for the school which he will use in assisting prospective students with special needs.

The criteria for educators at Kreativa Elementary School in general are being Muslim, like the world of children, and education in accordance with the required 
position, while the complete criteria for educators can be described, as follows:

a. Maximum age of 35 years

b. Muslim

c. Women wear Muslim clothing, while men don't smoke

d. Have the ability to teach and passion in teaching

e. Loves children

f. Fast learner, creative, disciplined and innovative

g. Team work oriented

h. Have good loyalty

i. Domiciled in Bogor and willing to conduct a series of selections required by schools in Bogor.

Prospective educators at Kreativa Elementary School are required to pass several series of tests, including administrative selection, written tests, reading tests of the Holy Qur'an, microteaching tests, and interview tests conducted by the principal and the foundation's HR department. The criteria for the management section are that they have at least 5 years of experience and show dedication, loyalty, and have the same vision for the institution. The above criteria are set by the school to maintain the quality of human resources who serve as education managers at Kreativa Elementary School.

The method of grouping student activities used at Kreativa Elementary School for the basic application of the 5 pillars is divided into 2 activities, namely learning activities in class and habituation activities at school. The learning materials used for the teaching and learning activities of students in the classroom must also be integrated with the basic 5 pillars of the school. Learning themes that exist in the 2013 curriculum, are then also integrated with existing values on the basis of the 5 pillars. Then the habituation activities for the application of the 5 pillars are carried out through:

a. Engineering school

School creates an environmental atmosphere that is able to remind students to always apply the value of the 5 pillars of the school. for example, such as: display arrangement of motivational words and others.

b. Exemplary from the human resources managing education

The facilitator and school management always provide an example for the application of the 5 pillars to students, for example, such as: the use of positive language in schools and showing good habits carried out by leaders.

c. Policy

The rules set by the school must be implemented by all human resources in the school. For example, such as: zero plastic zone policy and student involvement in student led conferences.

d. Foundation and school activities

To strengthen and instill students' habits of behavior at school, all activities organized by foundations and schools are always linked to the basic 5 pillars. for example leadership day, market day, ozone day commemoration, and holiday celebration.

\section{Sub Focus 3: Directing}

At the directing stage, the school has the goal of creating an outstanding school that develops students' Islamic moral achievement. Facilitators are assigned to help achieve these goals. The leader provides direction and motivation to the facilitator to stay on the right track in achieving school goals. This is in line with the opinion of Arabiun [11] which states that direction is to move organizational resources to work efficiently to achieve organizational goals.

Delegation of authority in direction starts from the director of the foundation who delegates authority to all support management including school management. The Principal of Kreativa Elementary School delegates authority to the deputy principal and the facilitator, either directly or in stages. The directing process is carried out routinely and in stages. The director of the foundation every month provides direction and motivation for school management. Furthermore, the principal will continue the direction given by the director of the foundation to the deputy principal and the facilitator on a regular basis every month through a grand briefing. The school principal also briefed the vice principal and forwarded it to the facilitator every week regarding the student learning program.

The implementation of education management is carried out by referring to the planning and division of tasks that have been determined, while the implementation of the education program is carried out according to the agreed educational calendar, as well as the implementation of tasks in accordance with the task description stated in the assignment. The learning process adapts to the themes in the 2013 curriculum which is integrated with the basic 5 pillars of the school and has been adjusted to the age development of students. Activities outside of classroom learning are carried out by the person in charge of activities who have been appointed by the school principal as the activity implementation team.

Implementation of the Education Program that supports the cultivation of the 5 pillars of basic values at Kreativa Elementary School, including:

\section{a. Islamic}

Learning to strengthen Islamic religious learning through learning tahsin is to recognize the letters of the Qur'an and how to pronounce it according to the rules of tajwid, while learning tahfidz is to strengthen memorization of the Qur'an. The memorization of the Qur'an is strengthened again through muroja'ah activities with recitation, memorization, understanding, and experiences of the Qur'an. The method of memorizing the Qur'an for students at Kreativa Elementary School uses the UMMI method given by a certified Qur'an facilitator. In addition, students also pray 5 times a day and pray Duha in congregation with the prayer priest who alternately. The school also organizes tasmi 'Al Qur'an activities, which is an activity to show students the ability to memorize the Qur'an. 
b. Green

This pillar teaches and instills in students about attitudes, habits, and learning related to the surrounding environment. Schools instill the value of concern for the environment through "the take out the trash is cool" program (ASIK). Students are required to dispose of garbage in its place according to predetermined categories, namely plastic waste, paper waste, and leaf litter. The school has also prepared a tool for chopping the leaves that have been collected by students. In addition, students also carry out activities related to the use of waste, namely Lusa Ok (Communal Organic Garbage Hole), which is a place to decompose organic waste such as leftovers from students' lunch into fertilizer. Schools also implement a zero plastic policy, a program to reduce the use of plastic in schools. Therefore students bring their own place to eat and drink from home.

\section{c. Leadership}

The strengthening of student leadership values is carried out by schools through the application of 7 habits by Stephen Covey [6]. Kreativa Elementary School provides understanding for students so that they can become leaders for themselves and their groups. Habits that students must practice in relation to the 7 habits include: Be Proactive, for example being responsible for the choice of students; Begin with the end in mind, for example, students must know what to achieve during one day; Put first things first, for example, students must determine priorities that will be carried out for one day; Think win-win, for example students should not be selfish and respect the decisions of others; Seek first to understand than to be understood, for example, students must be able to listen to other people's suggestions; Synergize, for example students can collaborate with anyone; and Sharpen the saw, for example students always manage their time well and always pray before doing important activities. In order to support the 7 habits leadership application of students, the school provides the WIG (Widly Important Goals) program which is a common goal to achieve. WIG is a target that has been set for students to implement such as 5 minutes of reading a book every day and discipline to fill in the attendance / attendance list. At the school there is also a lighthouse team that is formed to be responsible for the activities of instilling the value of student leadership. Besides that, the school also provides self-development programs as a support for potential development for students.

\section{d. Children-Friendly}

Learning at Kreativa Elementary School pays attention to the development of the child's age and the needs of students, namely students who are in grades 1-3 or lower class prioritizing learning life skills, strengthening morals and character, independence and strengthening of reading, writing, and calculating, while students who are in grades 4-6 or higher classes began to focus on broad academic learning. Schools provide a comfortable atmosphere at school so that students can learn comfortably, such as using positive sentences, avoiding bullying behavior towards fellow students, and developing self-potential that students have.

\section{e. Inclusive}

Schools give equal rights to all citizens to receive education, including children with special needs to learn together with other ordinary children through inclusive education programs. Students with special needs have been prepared by the facilitator as a companion for children with special needs to provide understanding and reinforcement related to the learning material given in class. Learning for students with special needs is combined with ordinary children in one class, but there are certain hours that are pulled out (pull out) to study in the Individual Learning Program (PPI) in the PPABK room. PPI focuses on learning centers, including: cognitive centers, self-development centers and gross motor skills, language centers and fine motor skills.

Kreativa Elementary School has compiled rules that must be obeyed by all school members to serve as guidelines in acting and impose limits on the education process at school so that all school members behave on the right track in order to achieve school goals. Regulations for human resources for school administrators such as management, staff, and facilitators are regulated in staffing regulations set by the foundation's HR and general management department. In addition, there are regulations that are implemented in one learning year that have been agreed upon by all school management human resources at school work meetings. The rules that are applied to all students are outlined in the school rules which are contained in the Kreativa School handbook. The handbook contains complete information regarding the vision, mission, learning programs at the school and the role of parents in assisting the learning process of students.

\section{Sub Focus 4: Controlling}

At the controlling stage, control is carried out by the process of monitoring and evaluating the learning outcomes of students and the performance of the facilitators. Routinely, the school principal monitors ongoing activities to ensure the implementation of activities is in accordance with the prepared plan. The school principal also ensures that the target school goals, student learning, and facilitator performance can be achieved. Likewise, Chairunnisa's opinion [12] states that control is an effort intended to ensure that the organization of organizational activities is carried out in accordance with the plans that have been made and compiled. 
The authority of monitoring and evaluating school education programs is exercised by the principal. The principal as a supervisor is responsible for monitoring, fostering, and improving the process of educational activities in schools. The authority of the school principal is assisted by the deputy principal to monitor and evaluate the facilitator and the learning process in the classroom. In its implementation, the authority of the school principal is also assisted by the facilitator to monitor and evaluate the learning process of students. The foundation has formed a quality assurance management section to carry out an audit of the education quality management process in schools.

Monitoring and evaluation of facilitators as well as educational programs are carried out by school principals on a monthly, semester and annual basis. Monthly evaluation is carried out through grand briefing activities. Each semester facilitator evaluation uses the Key Performance Indicator (KPI), while the annual evaluation is carried out through school work meetings. The principal is assisted by 4 deputy principals to conduct monitoring and evaluation of facilitators and the learning process in class every week. The deputy principal forwards the results of the evaluation to the principal. Foundation administrators monitor the implementation of education programs every month through meetings with school management. Monitoring and evaluation of students is carried out through attitude assessments which are carried out every day, mid-semester assessments, and final assessment of the semester. The mechanism for monitoring and evaluating children with special needs is the same as ordinary children, but it is more flexible to adapt to the development of students.

The instrument for monitoring and evaluating human resources for school management uses KPI which are assessed in stages. Monitoring and evaluation of students uses a draft of daily observations recorded in anecdote books, midterm exam questions, and final semester exam questions. These instruments are arranged by the school according to the learning provided to students, especially students with special needs. In addition, there is a National Standard School Examination (USBN) for grade 6 students.

The school management has prepared a reporting mechanism for the results of monitoring and evaluation of the Kreativa Elementary School education program, which is then reported to Yasmina Foundation every year. Monitoring and evaluation reports are also reported directly through monthly meetings with the management of the foundation. The mechanism for reporting the results of monitoring and evaluation of students through narrative report cards and semester reports. The narrative report card contains a description of the learning progress of students and the results of the midterm test scores reported at mid-semester to parents through the principal's endorsement. The semester report card contains student learning achievements during one semester of learning and is reported each semester to parents through the principal's approval.

Supporting factors for the implementation of educational programs at the Kreativa Elementary School include human resources, parental support, and foundation support. The quality of human resources in managing educational programs is highly considered by schools. Competency improvement is carried out to improve the quality of facilitators in providing learning materials to students. Parental support for students is by creating a conducive learning atmosphere at home so as to strengthen the learning carried out by Kreativa Elementary School. Support from the foundation through competency improvement activities carried out for facilitators and parents of students is expected to have an impact on strengthening the character of students. The foundation also always carries out activities that are in line with the learning program at school so that students participate and learn from these activities. Starting at the end of February 2020, which has become an inhibiting factor for the implementation of the education program at Kreativa Elementary School is an unpredictable condition due to the emergence of the Covid19 pandemic which is being experienced by all countries in the world which affects all areas of life, one of which is the education sector. The education that has been implemented at Kreativa Elementary School relies on direct interaction and face to face with students, but as a result of Covid-19 the strategy must change from offline to changing using online learning methods. This is a challenge for Kreativa Elementary School to continue to provide learning services for students in the current new normal era.

The continuous implementation of the 5 pillars in schools has had an impact on the achievement of school goals, this is understandable considering the attitude of students who have Islamic character and also the achievements of schools and students. The awards received by the school include Adiwiyata school, environmentally cultured school, leadership lighthouse school, school for providing inclusive education, and humanitarian awards. While the achievements obtained by students include the winner of the Al-Quran tahsin and tahfid, the winner of the mathematics competition, and other champions that were obtained from developing the potential of students. In addition, the impact of implementing the 5 pillars can be seen from the habits of students at school and at home. Students appear to be more confident, disciplined, responsible, active in learning and worship, as well as more concerned about the surrounding environment. Students with special needs also appear more confident, do not hesitate to mix with others, actively play and learn. All students who graduate from Kreativa Elementary School can continue their education to the junior high school level.

Students who graduate from Kreativa Elementary School receive a certificate according to the provisions of the government through the Bogor City Education Office, which has the right to continue to state and private junior high school education units. Kreativa Junior High School gives priority to Kreativa Elementary School graduates who will continue their education, both regular children and children with special needs. 


\section{CONCLUSION}

School management plays an important role in achieving school goals. Management is used by an organization to achieve its goals. Schools implement management functions starting from the planning, organizing, directing, and controlling processes properly. The Kreativa Elementary School realizes the development of Islamic morals for students by implementing 5 pillars: Islamic, Green, Leadership, Children Friendly, and Inclusive as the basis for implementing educational programs. The success of implementing the 5 pillars to achieve school goals is also supported by the supporting factors for the implementation of the education program at school, including human resources, parental support, and foundation support. In addition, there are factors inhibiting the implementation of the education program at school due to unpredictable conditions. The Covid-19 pandemic requires school which previously relied on the interaction and direct experience of students, to turn into online learning. This is work that must be done by school so that learning can run smoothly. The application of the 5 pillars of school has an impact on the achievement of school goals. The results of the implementation of the 5 pillars that are consistently carried out by schools can be seen from the achievements of the school and students. In addition, the impact of learning at school can be seen on the character and habits of students at school or at home. Students are more confident, disciplined, responsible, active in learning and worship. In addition, students are more concerned with the surrounding environment.

\section{REFERENCES}

[1] Siswanto, B. 2011. Pengantar Manajemen. Jakarta: Paragonatama Jaya.

[2] Tatang S. 2015. Manajemen Pendidikan Berbasis Sekolah. Bandung: CV. Pustaka Setia.

[3] Arif, Saiful Nur dan Zulkarnain, Iskandar. 2008. Dasar-Dasar Manajemen dalam Teknologi Informasi. Jurnal Saintikom. 5(2): 236-247.

[4] Hasan, Md. Mahmudul. 2016. Islamic literature: definition, nature, and scope. IIUC Studies. 13: 43-52.

[5] Cabral, C. 2019. Green Competencies: Construct development and measurement validation. Jurnal of Cleaner Production. 235:887-900.

[6] Covey, S.R. 2008. The Leader in Me. Terjemahan Fairano Ilyas. Jakarta: Gramedia.

[7] Risminawati dan Rofi'ah, S.N. 2015. Implementasi Pendidikan Ramah Anak dalam Pembentukan Karakter Siswa Kelas Rendah SD Muhammadiyah Program Khusus Kotta Barat Tahun Pelajaran 2013/2014. Jurnal Profesi Pendidikan Dasar. 2. (1): $68-76$.

[9] Mahmud, Akilah. 2019. Ciri Dan Keistimewaan Akhlak Dalam Islam. Sulesana. 13. (1): 29-40.

[8] Robinson, D. 2017. Effective Inclusive Teacher Education For Special Educational Needs and
Disabilities: Some More Thoughts On The Way Forward. Teaching and Teacher Education. (61):164178.

[9] Sutikno, Sobry. 2012. Manajemen Pendidikan Langkah Praktis Mewujudkan Lembaga Pendidikan Yang Unggul. Lombok: Holistica.

[10] Nurochim. 2016. Administrasi Pendidikan. Bekasi: Gramata Publishing.

[11] Arabiun, A.G. 2014. The Importance of Management for Growing and Developing Agribusiness SMEs: Designing a Conceptual Framework. International Review. 1. (2): 25-44.

[12] Chairunnisa, Connie. 2016. Manajemen Pendidikan dalam Multi Perspektif. Depok: PT. Rajagrafindo Persada. 